\title{
Where to Vocational Education in Kenya? Is Analysing Training and Development Needs the Answer to the Challenges in this Sector?
}

\author{
Susan W. Ngure \\ Edith Cowan University, Western Australia, Australia \\ s.ngure@ecu.edu.au
}

\begin{abstract}
This paper examines training and development (T\&D) systems in the technical, vocational education and training (TVET) in Kenya. It is in response to the Kenya Vision 2030 document that identifies TVET as the anchor of its economic pillar through science, technology and innovation to boost Kenya's industrialisation status. The document notes that skills training faces challenges such as mismatch of skills between the training institutions and the industry, and disparities in accessibility at all levels. This paper seeks to explore whether the accurate assessment of training needs is the answer to the challenges faced by the training program. Data for this study were collected from scrutinising previous research papers and government documents, interviews with four senior education officers drawn from the education ministries and the Kenya Institute of Curriculum Development (KICD), six trainers from technical training institutes and two from a youth polytechnic. Observations were made in the TVET institutions participating in this study. Data were analysed using content analysis and presented by means of description. Findings identified the following challenges: a rigid and unresponsive curriculum, inadequate methods of training and development needs assessment (T\&DNA), lack of stakeholder involvement in curriculum design, inadequate numbers of specialised staff at the KICD, poor training methods, obsolete tools and insufficient equipment, political interference and multiple providers. The author concludes that the introduction of a comprehensive T\&DNA is indeed a prerequisite for a relevant and adaptive T\&D program; however, additional factors such as the right equipment, qualified trainers, a conducive economic, social and political environment, and sound program coordination are also essential to its success. The paper is divided into seven sections: introduction, background to the research, problem statement, methodology, findings, discussion and research conclusions.
\end{abstract}

Keywords: Technical vocational education and training, skills, Kenya, training and development needs analysis, training objectives

\section{Introduction}

A successful skills training and development (T\&D) program is an integral part of a dynamic workforce, and is a prerequisite for economic and social development of a country. Technical, vocational education and training (TVET) can be broadly interpreted as the development of ways of learning and the acquisition of attitudes that facilitate success at the workplace (Munro, 2007). The aim is to contribute to equity and access to training and social responsibility by stimulating competitiveness and entrepreneurship to realise life-long learning concepts (Masson \& Fretwell, 2009). TVET plays an important role in supplying skills requisite for improved workers' productivity, economic competitiveness, occupational integration, raising income levels and expanding opportunities for employment (Bennell, 2000; Budría and Telhado-Pereira, 2009). In addition, formal education and work experience enables employers and owners to improve methods of production, enhance product quality, convey quality information to the users, identify markets, and manage human and other resources, all of which offer students a competitive edge (Sonobe, Akoten, \& Otsuka, 2011). TVET encompasses on-the-job training, apprenticeships, vocational secondary schools, sector-specific institutions, and vocational pathways within comprehensive schools (Rodgers \& Boyer, 2006)-aspects which can serve as a practical and effective ways of skills upgrading. Moreover, it has been established that graduates with jobspecific skills have a higher potential of being more productive and more equipped to execute tasks for which they have been trained (Rodgers \& Boyer, 2006). For instance, countries such as South Korea, Taiwan and Japan invest highly in vocational school systems to address challenges brought about by a scarcity of skilled workers (Tilak, 2003). These countries have introduced stringent quotas and entrance 
examinations to limit university enrolment figures and encourage enrolment in the TVET system. As a result they have had accelerated industrial and economic growth, due to a vibrant, skilled middle-level workforce.

In addition apprenticeship, which is a form of formal training involving supervision by an experienced worker or master during practice and theory, is practised all over the world in different forms and structures. It has been the traditional method for training tradesmen such as technicians, mechanics, electricians and carpenters (Stone, 2010). According to United Nations Development Programme [UNDP] (2010), apprenticeship system in Kenya involves young people being attached to ongoing projects in businesses and local industries under agreement or corporate social responsibility. The Kenya government places a lot of importance on skill training and has committed large amounts of resources to this sector over the years. However, the program faces serious impediments in its design, implementation, monitoring and evaluation processes. This paper is a response to challenges issued by the Government of Kenya in two documents: the 2005 Kenya Educational Sector Support Program (KESSP) document Delivering Quality Education and Training to all Kenyans and the Kenya Vision 2030 blueprint (Government of Kenya [GoK], 2007). The challenges addressed mainly cover two aspects of training: relevance (relating to the poor quality of skills produced by the training institutions and the mismatch of those skills with those demanded by the industry), and accessibility (relating to low funding levels and the location of training institutions). Other challenges issued relevant to this paper cover the poor coordination of training services, inadequate numbers of personnel to design and implement the curriculum, poor methods of training needs analysis and the use of obsolete tools and equipment (GoK, 2003b).In response to the government's challenges, the author throws the spotlight on Kenya's TVET to examine how well it's training and development (T\&D) systems respond to the country's skill needs. Prompted by repeated reference to TVET's "mismatch in skills" in reports and research papers (suggesting that the T\&D is either not based on the requirements of the industry, or the instruction methods do not produce the standards of skills needed by the industry), the author investigates whether the implementation of a national comprehensive training and development needs assessment (T\&DNA) will lead to a more responsive curriculum for the training. The paper sheds new light on TVET's shortcomings taking the reader to a deeper understanding of the system.

\section{Research Background}

To develop Kenya's social and economic advancement, skill training is intended to play two critical roles: one, offer training prospects and occupation growth for school graduates; and two, provide experienced labour for all levels of the country's economy (GoK, 2003a, 2007, 2008a). Due to scarce opportunities in paid employment nationwide, the skills developed are expected to lead to self-sufficiency, poverty alleviation and to advance Kenya's industrialisation processes (UNDP, 2010). With the drastic rate of dropout seen in the educational system, the importance the country attaches to TVET is magnified by the number of potential trainees expected to benefit from the program. According to GoK (2005), of approximately 600,000 graduates of Kenya Certificate of Primary Education, only 55 per cent (or $350,000)$ proceed to secondary schools. At the end of four years of secondary school, only 20,000 of 200,000 graduates of the Kenya Certificate of Secondary Education enter universities. The 250,000 primary school and 180,000 secondary school graduates who do not proceed with regular education are expected to be catered for by the middle-level colleges to which TVET institutions belong.

The training is vulnerable to social, economic and political climate current in Kenya. For instance, Presidential Circular No. 1/2003 on Organization of the Government, placed the management of it under twelve government ministries, among them education, water, local government, tourism, human resources and health (GoK, 2003c). Additionally, TVET operates within several Acts of government, as illustrated in Figure 1 below. The absence of a comprehensive legal framework and the existence of different sectorial statutes have led to policy duplication and conflict in the management of the training program (UNDP, 2010). Traditionally, the Kenyan government has managed most of the training institutions, but Government Sessional Paper No 6 of 1988 encouraged private investors to invest in the sector (GoK, 1988), a strategy that led to the mushrooming of private establishments countrywide, inevitably resulting in conflict and irregularities because the requisite training structures to support this strategy were not put in place (Ngerechi, 2003). 
A glance at TVET enrolment figures indicates a worrying gender bias. For example, the 2007 enrolment figures for the highest level-the national polytechnics that train technologists and advanced technologists show that 62 per cent of the learners were male and 38 per cent female. At the middle level institutions, this ratio changed to 55 per cent male and 45 per cent female, whereas at the lowest levelthe youth polytechnics - there was gender parity. Women have a lower participation rate than men at the higher levels of TVET because traditionally in Kenya technical education has been the preserve of men and, in keeping with cultural beliefs among most communities, women are discouraged from enrolling in the higher level programs (Ngerechi, 2003). Internationally, enrolment figures show a similar trend with men concentrated in the technical and engineering courses, while women take business-related and domestic-related courses, which are mostly concentrated at the lower levels of training (Bennell, 2000; Budria \& Telhado-Pereira, 2009). This has led to a downward spiralling path of role segregation and financial inequality.

\section{Figure 1: Legal framework governing TIVET}

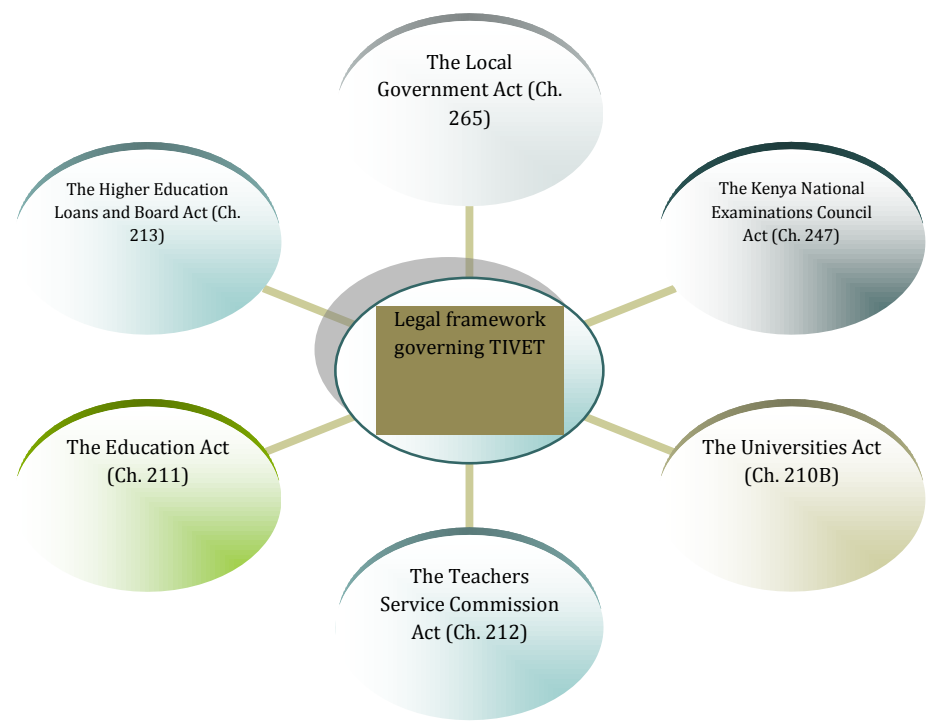

Inequality also exists at the financial level for would-be learners. According to Bennell (2000), the high costs of providing and running TVET courses in many African countries is borne by the trainees, who are required to pay for their tuition. High costs lead to expensive courses, which, understandably, most high school leavers cannot afford, therefore deterring many potential and needed entrepreneurs. Coupled with this, in Kenya there is no financial structure for students joining technical institutions to obtain study loans, unlike their counterparts at the universities who benefit from funding through the Higher Education Loans Board (Nyerere, 2009). It has been widely acknowledged by various studies and policy documents that as much as 70 per cent of skill training for the small scale business sector in Kenya takes place at the workplace, usually through apprenticeship training (Barasa \& Kaabwe, 2001; Bowen, Morara, \& Mureithi, 2009; UNDP, 2010; Wachira, Root, Bowen, \& Olima, 2009). In addition, Golding, Brown and Foley (2009) acknowledge that a similar percentage of all skill training in Canada and Australia takes place at the workplace in a wide range of social settings such as the home, worksites, and leisure and community activities.

In many African countries, labour market dynamics have expanded training objectives from being simply economic to embracing social imperatives, including those of fighting poverty and employing the youth (Johanson \& Adams, 2004). Furthermore, the aim of workforce training should be geared towards effecting change in the labour market and addressing social inequalities since "policies that succeed in changing the gender and racial imbalances that exist in vocational training may carry over their effects as those trainees enter the workforce" (Rodgers \& Boyer, 2006, p. 309). Regrettably, in Kenya, impediments such as gender and financial imbalances have curtailed the advance of TVET as a vehicle for social 
inclusion. To ensure that training systems respond to their people's aspirations, countries such as China, Germany, Mauritius, South Korea, the UK and USA ensure adequate links exist between industry needs and the training offered by projecting future skills requirements through conducting continuous needs analysis (Organisation for Economic and Co-operation Development [OECD], 2006). Others, such as South Korea and India, keep a comprehensive skills inventory leading to demand-driven training that addresses skill gaps in the industry. In addition, the German training system is largely employer-driven and emphasises continuing education that is based on three tenets: being action-oriented, practice-oriented and application-oriented (Hippach-Schneider, Krause, \& Woll, 2007; UNDP, 2010). Kenya could emulate such successful national training systems to safeguard national, regional and global training goals.

Problem statement: The GoK policy states that the main objective of TVET is "the provision, promotion and co-ordination of lifelong education, training and research for Kenya's sustainable development" (GoK, 2003b, p.4). Four specific objectives are derived from the main objective:

- to provide increased training opportunities for school leavers that enable them to be self-supporting

- to develop practical skills and attitudes, which lead to income-generating activities in urban or rural areas through salaried or self-employment

- to provide technical knowledge and vocational skills necessary for the growth of agriculture, industry and commerce

- to produce people who can apply scientific knowledge to the solution of environmental problems (GoK, 2003b, p.9).

TVET objectives are formulated to address different economic sectors in the quest for the country's industrial growth. Despite such elaborate and sound policies, implementation has been inadequate and often uncoordinated, leading to unrealised objectives (GoK, 2007). In addition, a committed process of monitoring and evaluation (M\&E) is needed, involving regular data-gathering and scrutiny to inform decision-making at all levels and propel corrective measures (GoK, 2008c). The status of TVET suggests that there is a need to carry out intensely focused planning on a strictly regular basis to render the program more responsive, flexible and accessible to the Kenyan public and the industry. This research paper examines whether the entrenched problems and challenges experienced in the TVET program can indeed be addressed by carrying out a more rigorous and comprehensive T\&DNA. The question addressed is:

Will a comprehensive T\&DNA lead to a more responsive TVET curriculum? The importance of accurately identifying the T\&D needs is expounded by numerous government reports which observe that vocational education in Kenya lacks relevance to the demands of industry (GoK, 2003b, 2005, 2008a). The Kenya Vision 2030 document further notes that matching the skills obtained in the vocational institutions in the country to market demand presents a challenge at all levels of the education system and attributes this position to inadequate facilities as well as poor methods of needs identification (GoK, 2007). To be relevant, therefore, a training system needs to be demand-driven to include opportunities for the contemporary and imminent skill needs of the whole country. Fluitman (1999) underlines the reasons for cases such as this:

- A national training system may be considered to lack relevance if it does not produce, or no longer produces, enough of the skills that contribute in one way or another to meeting macro-economic and social objectives such as income growth and equity; or if it does not respond adequately to changing circumstances, notably those in the labour market. (p. 57)

- In addition, the KESSP document, which was prepared to guide educational programs for ten years (2005-2015), highlights the low participation of the private sector and other stakeholders in TNA, curriculum design and implementation (GoK, 2005).

\section{Methodology}

To examine the research question, the author sought views directly from those people who bear the responsibility of transforming T\&D policies into good outcomes for their students. Questions about curriculum design and implementation were put to four senior education officers drawn from Ministry of Education Science and Technology (MoHEST), Ministry of Education (MoE) and KICD, and, eight 
trainers-six from technical training institutes and two from a youth polytechnic. Four training institutions were identified for interviews with the trainers and trainees by the use of purposeful sampling to cater for size, ownership (private or public) and different institutional types. At the end of the sampling process, the institutions selected included: a youth polytechnics (YPs), one institutes of technology (ITs), one technical training institute (TTIs) and one private technical institute. This method of sampling was informed by Denzin and Lincoln (2011), who observed that many qualitative researchers use purposeful, instead of random, sampling by looking for individuals, groups and settings where the processes under study are most likely to occur. In-depth interviews were also held with a KICD officer, two Education officers and a curriculum development consultant in the same ministry. The first three had been identified early in the planning, but the fourth was recommended by one of the education officers, due to his wide experience in the sector. The four officers were viewed as authorities in the training sector because they held influential positions in their ministries. Although the above stated respondents are an ideal sample for a qualitative study, they nevertheless represent a very small percentage of the total population. Only four institutions out of approximately 1,500 registered by MoHEST (UNDP, 2010), and four education officers out of a possible 750 employed by the government were involved in this study.

Table 1: Study respondents

\begin{tabular}{|l|l|l|}
\hline Stakeholder & No. selected & Code \\
\hline Trainers & 8 & TSN1-TSN8 \\
MoE education officer & 1 & E01 \\
MoHEST Education officers & 1 & E02 \\
MoHEST consultant & 1 & E03 \\
\hline KICD officer & 1 & E04 \\
\hline
\end{tabular}

Data were collected using semi-structured interviews tools with the twelve respondents. Although semistructured interviews rely on pre-formulated questions for guidance, they also allow respondents to talk freely about those things that are of interest and importance to them (Baker \& Foy, 2008). Observation was used in the institutions under study to discern the day-to-day processes and activities. Importantly, Baker and Foy (2008) stress that observations ". . . avoid the possibility of distortion that may arise when people are asked to report their own behaviour" (p.147). In addition, the researcher gathered data from pertinent government documents, and archival records, in line with recommendations made by Yin (2004).Content analysis, a systematic method of qualitative data analysis that seeks structures and consistencies (Myers, 2009) was used to deal with the enormous amount of data collected. This involved categorising and coding data using thematic areas that were identified in this study. Each respondent was given a code thus: trainers, TSN1 to TSN8 and education officers E01 to E04. The findings are presented by using descriptive methods.

\section{Findings}

Training and development needs analysis involves two parts: first, training needs analysis (TNA) that involves gathering data from stakeholders using different methods of data collection, analysing it and presenting it; secondly, formulating objectives to guide training activities and training evaluation. These processes are discussed in the following section. In Kenya, ideally, the responsibility of conducting a TNA is placed on MoHEST. Kenya Institute of Curriculum Development (KICD), the body that designs and develops the curriculum, is expected to realise the findings of the TNA by incorporating them into curriculum development. Data gathering is expected to be carried out at the institutions, the industry, past graduates, parents' organisations, education field officers and training providers. However, trainers 
conceded that although they understood industrial trends, they did not have the power to decide on what to include in curriculum revision, but relied on KICD for guidance. One of these, TSN3 had this to say, since the focus of the training is employment, the skills should be linked to the job market to ensure that there is no mismatch among the training and competencies required in the labour market. To this end, the government ought to conduct a skills analysis that will guide the institutions on what to offer. The centralised curriculum development faces implementation challenges in different parts of the country due to diversity in geographical, social and economic conditions. TSN6 and TSN7 expressed the need for a curriculum suitable for specific regions-for example economic activities like animal transport in the arid areas of northern Kenya and water transport in the lake region of Western Kenya. These two trainers also identified the lack of cross-regional representation in the identification of training objectives as a gap that ought to be filled. TSN6 further observed that

As things stand now, the curriculum is taught as if all areas have the same needs. Yet this is not true. For instance there is only one car in Lamu [an island town in the Kenyan coast] town-that of the district commissioner. What is the use of teaching people from this region automotive engineering skills that they are likely never to use? Their main modes of transport are donkeys and perhaps donkey carts should be given more prominence. Trainers further noted that their ministry already had well-formulated and researched, policy documents such as Skills Gap Analysis for Graduates of Youth Polytechnics, Vocational Training Centres and Out of School Youths (UNDP, 2010), A rapid appraisal on the status of technical and vocational education and training in Kenya (GoK, 2003b), and The National MSE Baseline Survey (1999). If implemented, these policies would lead to improved training. However, TSN4 and TSN5 observed that although most of these documents would make a positive change, they were drafted at ministry headquarters without authors being fully cognisant of the situation on the ground. These discrepancies between policy-makers and policy-implementers were accentuated by Barasa and Kaabwe (2001, p. 229): "there is a danger of widening the gap between policy and practice in contexts where policies and strategies for economic and educational development are based on impressionistic assumptions rather than empirical assessment of reality".

Although the officers were emphatic that TNA was carried out, an official of the Kenya Association of Technical Training Institutions (KATTI), who was also a head of one institution involved in this study, noted that the industry tended to send generalists such as training managers and human resources officers who did not have the capacity to participate meaningfully in curriculum deliberations. The KATTI official observed that ". . . lack of participation in curriculum design by technical plant managers, engineers, technicians and other professionals involved in research, design, production and E02 indicated that MoHEST occasionally undertook analyses that led to new blueprints or policies. For example, in 2003 there was a policy document, $A$ rapid appraisal on the status of technical and vocational education and training in Kenya (2003b) that formed the basis of the TVET investment program in the KESSP document. In addition, EO1 explained that this appraisal involved a multi-sector task force led by a university professor in the faculty of science and technology and included KEPSA, university researchers and public service officers. Data gathered from these players were then scrutinised through workshops that brought together all key actors in the skill use sectors. Indeed this research established that this kind of workshop was the primary mode of carrying out needs assessment.

In a responsive $T \& D$ curriculum objectives are expected to address training needs identified in the analysis phase by detailing what is to be taught, to whom, time allocation, teaching methods, learning materials and the physical facilities required. EO3 specified that the curriculum and examinations for the trade courses are designed and tested by the Directorate of Industrial Training (DIT); the craft and diploma courses are designed by the KICD and examined by the KNEC whereas universities manage their own courses and examination. Most of the private colleges follow the curriculum designed by the KICD, but some follow foreign curricula and exams. There are two curricula on offer at the TVET institutions: the old curriculum and the new curriculum. Former trains the workers to enter the job market, whereas the latter is designed for advancement to the next level (GoK, 2008b). E04 observed that the curriculum is outdated partly because of over reliance on donors for funding. The curriculum framework for TVET has remained rigid, concentrating only on institution-based, full-time training or long course programs, ignoring graduates from other programs components such as non-formal education, industrial training, on-the-job training, and trade tests, and even horizontal movement from one trade to an allied one. 
KICD strategic plan noted that syllabi development was done through a panel system that is unsuitable for TVET because it takes too long to respond to rapid changes in the industry (KIE, 2006). In addition, the researcher observed that the training institutions used aluminium and plastic materials while most of the small businesses were using traditional materials such as steel and timber for training and production of goods. EO3 added that in the TVET sub-sector, there are different curricula with varying training durations and entry requirements. Some institutions offer diploma programs for three months, others six months, and yet others one year, all of which are a wide variance from the two years recommended by KICD. This situation is attributed to the lack of a legal authority to govern curriculum development in the country. Trainers expressed their frustration with the TVET curriculum, which they felt was not up to standard. TSN8, a trainer at a youth polytechnic (YP), explained thus: Some institutions are still using the old industrial skills curricula. It is difficult to comprehend how a country that hopes to be industrialized by the year 2030 is still using a curriculum developed in the 1980s. Surely, the kind of cars and the technology at that time has changed significantly and the curriculum should reflect this. The curriculum should be revised every five years to ensure its relevancy. In his institution TSN4 informed the researcher that the curriculum for craft and diploma courses designed in 1992 was in use until 2008, when the institution implemented the revised curriculum in 2009. TSN4 noted that some institutions were still using the outdated 1992 curriculum, since the 2008 version was being introduced at different times in various training institutions.

Discussion: To answer the research question this study considers the expert opinion that was brought to the fore through interviews conducted with the respondents. The aim is to determine whether a comprehensive T\&DNA is the answer to the deficiencies observed in the TVET sector. This will be done by discussing two distinct phases of a T\&DNA: the training needs analysis and the training objectives, both of which affect the quality and relevance of a training program.

Training needs analysis: Three components of TNA were used to inform this research paper: organisation, task, and individual variables. Organisational needs analysis examines a particular organisation's aims and objectives, resource allocation and mechanisms of monitoring and evaluation. A task analysis defines performance targets, identifies training activities, and determines the knowledge, skills and proficiencies that aid in successfully performing these tasks. Individual analysis is concerned with determining job requirements and current and future skill levels of the workforce. The translation of an organisation's training needs into goals and objectives provides purpose and direction for a training program, other than merely copying or relying on what others are doing (Stone, 2010). Brown (2002) identified four objectives for a successful TNA: (1) to identify skill gaps; (2) to advocate for top management backing; (3) to gather data for use in monitoring and evaluation; and (4) to determine training benefits. Likewise, Ridha (1998) perceived TNA as the examination or analytical part of the training program which aims to determine if there is observed performance discrepancy-that is, if there is a difference between the level of performance and the expected outcomes. Accordingly, he suggested six key features that a sound T\&DNA should address: (1) training programs and contents, (2) training priorities, (3) assumptions behind the choices and priorities, (4) required resources, (5) timing of implementation and (6) the expected rate of progress and returns. This research used these six features to identify four relevant thematic areas of the TNA through examining the Kenyan vocational training system.

Training programs, contents and priorities: The Kenyan government has specified four issues for T\&D to address: quality, relevance, access and equity (GoK, 2005). A quality training program involves adequate facilities, well-trained instructors, effective monitoring, and evaluation mechanisms. Relevance is concerned with instructing what is demanded by the consumers of the training program through matching the training with the appropriate content. Access to training asserts that potential trainees should not face any hindrance in acquiring training; this would require locating the training institutions in areas where they are needed equipping them, and adequately funding programs to allow equal access training. In addition, to ensure equity, courses ought to be made attractive to male and females alike, the disabled, the poor and the marginalised (such as the pastoralists). This research established that most training institutions are located in the urban areas, learners are expected to pay for training, while monitoring, evaluation and quality control is not sufficiently carried out. To complicate issues, low levels of funding have resulted in skimming data gathering processes. For instance, TNAs are routinely done 
using advisory committees and examination results, shutting out major stakeholders. These methods of assessment cannot address core areas, like tracer studies, or follow graduate pathways. Training providers and employers complained that lack of a skills inventory leads the government to attempt to develop skilled workforce without addressing the skill problem and labour demands. Countless certificates offered by questionable training providers perpetuate the sceptical nature with which the TVET graduates are viewed by the industry. Furthermore, inflexibility of the program shuts out prospective learners who are unable to follow its strict programs, thereby missing out on a chance to upgrade their skills and competencies.

Timing of implementation: Different training programs require different lengths of implementation durations that are dictated by the training content, available resources and the reasons behind the training objectives. A comprehensive TNA guides the training providers on the amount of time needed to cover the curriculum since some courses may take just a few weeks and others much longer. Competencebased courses that address specific skills and proficiencies require less time than comprehensive programs such as diploma or degree courses. Flexible programs such as evening and weekend classes cater for those trainees who are already at the workplace but would want to upgrade their skills or change them altogether. Centralised regulations and uniform curriculum across the country fail to consider diverse learner needs, geographical and regional variances and particular industry requirements. Further, young people prefer short duration courses that provide them with a means of livelihood, as opposed to the longer two to three year courses, which may have been dictated by the past needs of the industry. Besides as van Eerde, et al., (2008) found out in some circumstances, the hours of training did not have a direct relationship to the organisational effectiveness.

Resources required: In Kenya it was established that the government funds T\&D through provision of equipment, trainers' salaries, research, monitoring and evaluation in TVET institutions and universities. The students in these institution pay for their accommodation and other services offered by the institution. The cost of training an artisan at the YP is borne fully by the government. To encourage women to enrol in the science and engineering courses, the government meets all their training costs. This funding situation would suggest that the TVET program is highly subsidised. However, the heads of public institutions specified that some students are unable to meet the required payments, leading to drop-outs, or delay in completion of courses. One major problem in TVET is that the impact of training is assessed based on the general environment, natural and economic resources, the business environment, use of appropriate equipment, demand and access to markets (Kingombe, 2008). This fails to acknowledge that competing ontological and political positions; and, diverse conceptions and understandings of the relationship between education and development in societies is marked by gross inequalities (Tikly, 2010). These competing program discourses that revolve around quality involves negotiating conflicting interests in the national and civil societies and which have varied levels both globally and to locally (Robertson, Novelli, Dale, Tikly, Dachi, \& Ndibelema, 2007)

Expected rate of return: In more responsive TVET programs, businesses would expect to benefit from more flexible, motivated and committed workers, while employees are expected to receive the psychological rewards of being appreciated by their employers (Tsang \& Ding, 2005). This is because inputs into a training program have an effect on the outputs that are reaped by the country, businesses and graduates. The effects of such inputs are mediated through intervening factors such as the wider competitive strategy of the organisation because investment in skills does not necessarily equate to higher productivity or better performance. It is therefore simplistic to assume that the relationship between inputs, processes and outputs of education are linear (Tikly 2010) such as the one suggested by Fluitman (1999). The AU (2006) observes that in the past, the quality of an education program was measured by the quantity and level of investment that was put into it. More recently however, the impact in terms of cognitive and emotional development, as well as the promotion of values and attitudes, has gained prominence. In addition to the input-output relationship, this study acknowledged the interrelationships among variables such as: the learner background, resource inputs and educational processes and also recognizes that outputs are complex, multi-directional and they vary according to different contexts. This is because the economic, socio-cultural and religious contexts can either facilitate or hinder the learning and teaching process (AU, 2006). 
Training objectives and curriculum designs: National training objectives provide direction for training providers and other stakeholders' interested in vocational training. This study identified five specific areas, to be addressed by vocational education syllabi and which are discussed below: delivery of quality T\&D, improvement of consistency and management by training providers, improving graduates' employability, promotion of life-long learning, and enhancement of the status and attraction of vocational education. These areas were informed by the African Union and confirmed as important by primary and secondary data.

Delivery of quality T\&D programs: Objectives are expected to address quality training and identify obstacles that hinder provision of TVET in the country and recommend for best ways to mitigate them. Training needs that are identified, and objectives that are formulated thereafter, categorise areas that necessitate updating and revision of curricula to safeguard its relevance and the optimum use of available resources. Information gathered from the institutions show that this area has been neglected in Kenya to the point that the government trades course, which is administered by the DIT is still using a curriculum designed in the 1980s. Using outdated curriculum is a failure by the government to set strategies that would link education and training to specific growth paths and prioritising skills and proficiencies that would lead to a more competitive edge (Tikly, 2003). Such strategies have been used to create newly industrialised countries like Korea and Japan. Duplication of the program and lack of ownership by the line ministries could account for the laxity in curriculum development in Kenya. Education officers supposed that KICD has been unable to regularly update and revise the curriculum due to insufficient funds, poor research and lack of adequately qualified personnel. UNESCO suggests that updating and revising of curricula in most African countries mostly takes place after a major crisis in the labour market or critical problems of graduates' unemployment (UNESCO, 2009). In addition, there is a lack of proactivity in most countries, and the response to curriculum challenges is ad hoc and lacks the capacity to address industry needs. A training fund based on employers' payroll levies could support skills development. In an unregulated business sector, this could prove a difficult task that would call for concerted effort to first register the businesses and then convince the business owners of the need to support the levy. Lessons can be drawn from a number of African countries, such as Cote d'Ivoire, Mali, Mauritius, South Africa, and Tanzania, who have introduced training levies that have helped ease the problem of funding (African Union [AU], 2007). In addition, in countries such as Germany and France where contribution to training levies is compulsory there is a better inter-firm cooperation (Cooney \& Long, 2008).

Improving consistency and management of training providers: Stakeholders observed that national objectives that guide appropriate, consistent and management practices of the MoHEST training managers and providers ought to be incorporated into national policies. In addition, they held that solid leadership abilities and professional management practices that are aligned to national policies are necessary for successful outcomes. Consistency of the T\&D program is complicated by different curricula with varying training duration and entry requirements, some of which is foreign. Using foreign curricula has difficulties because cultural identities differ in how they conceptualise trade, in their outlooks and temperaments, their spoken and non-verbal rationalisation and in their perceptions (Munro, 2007). In addition, an individual's ability to internalise learning is influenced by his community's values, social biases, motivation and other social hierarchies and economic status (Barber, 2004). Strategies that seek to improve the consistency of training providers need to consider informal training and the issue of certification. The inability for informally trained mechanics to procure formal trade certification denies them a chance to legitimately access formal sector employment where job security, wages and pensions are higher (Barber, 2004). This is despite the fact that these mechanics may be having more superior skills than their formally trained counterparts. Atchoarena and Delluc (2001) found that ignoring the informal sector lead to inherent deficiencies in training programs and their delivery modes in Cote d'Ivoire. Part of the reason is that most TVET programs train a fairly large amount of general content that is not linked to the specific skills needed for the mostly informal local labour markets (UNESCO-UNEVOC, 2008).

Improving employability: Since the primary purpose of training is employability, objectives that give trainees assurance of being absorbed into the labour market are vital. Employability presumes the attainment of skills that correlate with the labour market demands. The primary motivation for students' 
decision to train instead of joining the workforce is to improve their chances of securing employment and raising income levels (Cox \& King, 2006). Thus, potential trainees require guidance in their choice of training programs by taking cognisance of their ability and academic qualifications, current and required skill levels, and by analysing jobs (van Eerde, et al., 2008). The critical aim in skills development is to match the acquisition of skills and competencies with the demand for such abilities in the industry, because if the trained graduates do not find jobs, joblessness is perpetuated leading to a waste of scarce resources (Johanson \& Adams, 2004).

Promoting life-long learning: National objectives that promote life-long learning acknowledge that skills in the workforce are not stagnant, but evolve in their relevance and practicability. The skills need to be upgraded continually through a life-long approach to learning and training in Kenya to ensure the development of quality systems (Wallenborn, 2010). Life-long learning can also assist learners whose earlier training was limited, to enhance their skills and proficiencies. Myriad TVET programs in Kenya make it difficult for employers to determine employment entry levels for graduates due to the wide range of certificates and diplomas, while local universities face similar complications admitting graduates at appropriate levels.

Enhancing the status and attractiveness of vocational education: An individual's perception and belief in their self-worth in the vocational setting and the extent to which they have faith to be fruitful in their endeavours, play an important role in learning. A common view of vocational education is that it largely benefits students who have a low academic ability and whose primary intent is a rapid entry to employment (Maliranta, Nurmi \& Virtanen, 2010; Munro, 2007). To help improve the TVET students' selfefficacy, therefore, there is a need to acknowledge that the main aim of advancing vocational knowledge is to develop an understanding of an aptitude and advancing this awareness in the perspective of the industry and the workplace, as opposed to the issue of academic capabilities.TNA can be performed through various means, such as performance analysis, interviews, advisory committees, surveys and questionnaires, tests, observations, document reviews and assessment centres (Brown, 2002; Hauer \& Quill, 2011). However, data gathered for this study indicated a limited means of assessing needs: interviews, examination results and advisory committees. Since the reach of these methods is restricted, most stakeholders are excluded from this activity, and this could explain the mismatch of the skills acquired and the available labour force needs and opportunities. In addition, even when a TNA has been conducted in Kenya (e.g. the MSE baseline survey of 1999), the results are not adequately communicated to stakeholders to make sense of the happenings in the market, resulting in training processes that are inadequate in scope and practice.

\section{Conclusion}

The aim of a T\&D program is to enable graduates to acquire knowledge, skills and attitudes, and to relate these to their daily activities. Furthermore, the results of a T\&D program ought to improve the country's productivity by making efficient use of the resources and to lessen problems related to high turnover, employee grievances, absenteeism, quality control issues, customer complaints and accident rates. An accurate assessment of training needs ensures the success of a T\&D program by suitably aligning the training activities to the needs of the consumers. In this paper, it was shown that TVET suffers from numerous and entrenched problems: a rigid and unresponsive curricula, poor methods of identifying training needs, lack of stakeholders' involvement in curriculum designs, inadequate numbers of specialised staff at the KICD to design and revise curriculum, poor training methods, and obsolete tools and equipment at the training institutions. It is also characterised by difficult social, political and economic aspects and multiple providers who do not necessarily follow the approved national curriculum. Analysing the skill needs of the Kenyan industries is prerequisite to a sound TVET program. Three analyses are required: first, individual needs where potential trainees' characteristics are analysed; task analysis, which identifies the frequency of the training lessons the quality and quantity of the T\&D program, where and how to acquire the skills for the industry and the conditions under which the tasks are to be performed; and, an industrial skill gaps analysis. This would result in an assembly of a skills inventory and a skill gaps data that would be addressed by the training institutions. Further the T\&DNA will gather data on the resources required, and the most responsive type of training be it formal, informal, apprenticeships etc. 
Findings of this paper acknowledge that TVET's challenges to supply the industry with qualified skills and labour are multifaceted. To turn the situation around a multi-level approach is likewise needed. Although the examination of training needs is vital for a programs' success, other factors such as training facilities and monitoring and evaluation mechanisms are necessary. Thus, there is a need for the country to expand skills training to improve productive labour by deliberately addressing the inadequate and out-dated physical facilities, materials and equipment needed for training and the envisaged productivity to achieve a more dynamic and competitive workforce for the Kenyan industries, and to propel the country to higher industrialised status (UNEVOC, 2006). Focus of this study was the T\&DNA processes for industrial skills training in Kenya. A comprehensive needs analysis for TVET program would involve gathering data from a variety of stakeholders such as employers, employees, trainers, trainees, book publishers, donor agencies and government officials. Yet this study's respondents were only two groups, education officers and trainers. Other researchers can extend this research by analysing different stakeholders to find out how they view the TVET program. In addition, a T\&D program has other components: training activities and training evaluation; two parts that can form an interesting area of study.

\section{References}

African Union [AU]. (2007). Strategy to revitalize technical and vocational education and training (TIVET) in Africa. In Meeting of the Bureau of the Conference of Ministers of Education of the African Union (COMEDAF II+) 29-31.

Atchoerena, D. \& Deluc, A. (2001). Revisiting Technical and Vocational Education in Sub-Saharan Africa: an update on trends innovations and challenges. International Institute for Educational Planning: Paris.

Baker, M. J. \& Foy, A. (2008). Business and management research: how to complete your research (2nd ed.). Westburn: Scotland.

Barber, J. (2004). Skill upgrading within informal training: lessons from the Indian auto mechanic. International Journal of Training and Development, 8(2), 128-139.

Barasa, F. S. \& Kaabwe, E. S. (2001). Fallacies in policy and strategies of skills training for the informal sector: evidence of the Jua Kali sector in Kenya. Journal of education and work, 14(3), 329-353.

Bennell, P. (2000). The impact of economic liberalisation on private sector training provision in Zimbabwe. Assessment in Education, 7(3).

Bowen, M., Morara, M. \& Mureithi, S. (2009). Management of business challenges among small and micro enterprises in Nairobi-Kenya. KCA journal of business management, 2(1).

Brown, J. (2002). Training needs assessment: A must for developing an efficient training programme. Public, Personnel Management, 31(4), 569-578.

Budria, S. \& Telhado-Pereira, P. (2009). The contribution of vocational training to employment, jobrelated skills and productivity: evidence from Madeira. International Journal of Training and Development, 13(1), 53-72.

Cooney, R. \& Long, M. (2008). Labour pains? Monash Business Review, 4(3), 40-42.

Cox, S. \& King, D. (2006). Skill sets: an approach to embed employability in course design. Education + Training, 48(4), 262-274.

Denzin, N. K. \& Lincoln, Y. S. (2011). The discipline and practice of qualitative research. In N. K. Denzin \& Y. S. Lincoln (Eds.), The SAGE Handbook of Qualitative Research (4 ed.). Thousand Oaks, California: Sage Publications.

Fluitman, F. (1999). The roots and nature of reforms in vocational education and training: An analytical framework and some examples. Prospects, 29(1), 55-65.

Government of Kenya [GoK]. (1988). Government Sessional Paper No 6 Nairobi: Government printer.

Government of Kenya [GoK]. (2003a). Economic recovery strategy for wealth and employment creation 2003-2007. Nairobi: Government Printer.

Government of Kenya [GoK]. (2003b). A rapid appraisal on the status of technical and vocational education and training (TVET) in Kenya. Nairobi.

Government of Kenya [GoK]. (2003c). Presidential Circular No. 1/2003 on Organization of the Government. Nairobi: Government Printer.

Government of Kenya [GoK]. (2005). Kenya education sector support programme (KESSP) 2005-2010: Delivering quality education and training to all Kenyans. Nairobi: Government Printers.

Government of Kenya [GoK]. (2007). Kenya Vision 2030. Nairobi: Government Printers.

Government of Kenya [GoK]. (2008a). Technical, industrial, vocational and entrepreneurship training strategy. Nairobi. 
Government of Kenya [GoK]. (2008b). The development of education: National report of Kenya. Nairobi: Government Printer.

Government of Kenya [GoK]. (2008c). MoHEST strategic plan 2008-2012. Nairobi: Govrnment Printer.

Golding, B., Brown, M. \& Foley, A. (2009). Informal learning: a discussion around defining and researching its breadth and importance. Australian Journal of Adult Learning, 49(1), 34.

Hauer, J. \& Quill, T. (2011). Educational needs assessment, development of learning objectives, and choosing a teaching approach. Journal of Palliative Medicine, 14(4), 53-508.

Hippach-Schneider, U., Krause, M. \& Woll, C. (2007). Vocational education and training in Germany: Short description. In Cedefop (Ed.). Luxemburg: Luxembourg: Office for Official Publications of the European Communities.

Johanson, K. \& Adams, I. (2004). Skills development in sub-Saharan Africa. World bank regional and sectoral studies. Washington: World Bank.

Kenya Institute of Education [KIE]. (2006). Strategic plan 2006-2007. Nairobi: Ministry of Education.

Kingombe, C. (2008). Evaluating the effects of vocational training in Africa. In African Economic Outlook 2008 (Ed.), (Vol. 61): Paris: OECD Development Centre Policy Insights.

Maliranta, M., Nurmi, S. \& Virtanen, H. (2010). Resources in vocational education and post-schooling outcomes. International Journal of Manpower, 31(5), 520-544.

Masson, J. \& Fretwell, D. (2009). The European Union: Supporting technical and vocational education. Techniques, 84(7), 48-51.

Munro, J. (2007). Fostering internationally referenced vocational knowledge: A challenge for international curricula. Journal of Research in International Education, 6(1), 67-93.

Myers, M. D. (2009). Qualitative research in business \& management. London: SAGE.

Ngerechi, J. B. (2003). Technical and vocational education in Kenya Paper presented at the Conference on the Reform of Technical And Vocational Education and Training (TVET) Gaborone, Botswana.

Nyerere, J. (2009). Technical, industrial \& vocational education and training (TVET) sector mapping in Kenya. Nairobi: Dutch Schokland TVET programme.

Organisation for Economic and Co-operation Development [OECD]. (2006). Policy framework for investment. A review of good practices.Paris: OECD.

Ridha, A. K. (1998). Training and development needs assessment: a practical model for partner institutes. Journal of European Industrial Training, 22(1), 18-27.

Robertson, S., Novelli, M., Dale, R., Tikly, L., Dachi, H. \& Ndibelema, A. (2007). Globalisation, education and development: Ideas, actors and dynamics. London: DfID

Rodgers, Y. \& Boyer, T. (2006). Gender and racial differences in vocational education: an international perspective. International Journal of Manpower, 27(4), 308-320.

Sonobe, T., Akoten, J. \& Otsuka, K. (2011). The growth process of informal enterprises in Sub-Saharan Africa: a case study of a metalworking cluster in Nairobi. Small Business Economics, 36, 323-335.

Stone, J. (2010). Managing human resources (3 ed.): John Wiley \&Sons Australia, Ltd.

Tilak, J. (2003). Vocational education and training in Asia. Journal of Educational Planning and Administration, 17(1), 1-16.

Tikly, L. (2010). Towards a framework for understanding the quality of education. Bristol, UK: University of Bristol.

Tikly, L. (2003). The African Renaissance, NEPAD and skills formation: An identification of key policy tensions. International Journal of Educational Development, 23(5), 543-564.

Tsang, C. M. \& Ding, Y. (2005). Resource utilization and disparities in compulsory education in China. China Review, 5(1), 1-31.

United Nations Development Programme [UNDP]. (2010). Skills gap analysis for graduates of youth polytechnics, vocational training centres and out of school youths. Nairobi: Government of Kenya.

van Eerde, W., Tang, K. C. \& Talbot, G. (2008). The mediating role of training utility in the relationship between training needs assessment and organizational effectiveness. The International Journal of Human Resource Management, 19(1), 63-73.

Wachira, M., Root, D., Bowen, P. A. \& Olima, W. (2009). An Investigation into informal craft skilling in the Kenyan and South African construction sectors. Cape Town.

Wallenborn, M. (2010). Vocational Education and Training and Human Capital Development: current practice and future options. European Journal of Education, 45(2), 181-198.

Yin, R. K. (2004). Case study methods (Revised Draft). COSMOS Corporation. Washington DC. 